\title{
A new bathyphotometer for bioluminescence measurements on the Armorican continental shelf (northeastern Atlantic)
}

\author{
Patrick GEISTDOERFER, Marie-Anne VINCENDEAU \\ Laboratoire d'océanographie, École navale, Lanvéoc-Poulmic, 29240 Brest Naval, France
}

(Received 8 January 1998, revised 23 July 1998, accepted 24 July 1998)

\begin{abstract}
A new bathyphotometer has been developed by the Oceanographic Laboratory of the French Naval Academy which has performed a series of in situ bioluminescence measurements since 1994. It is used as an additional probe to a Seabird @ CTD. It measures planktonic bioluminescence. It is associated with a SeaTech $®$ fluorometer. The Armorican shelf has particularly been investigated since July 1994. Results obtained in January and April 1995 off Brittany (France), at the entrance to the Bay of Douarnenez and in the northern Bay of Biscay are presented as examples. A method to separate the bioluminescence background from sharp peaks is presented. The strength of bioluminescence signals was related to seasonal planktonic biomass fluctuations, low in winter, higher in spring. (C Elsevier, Paris / Ifremer / Cnrs / Ird

marine bioluminescence / bathyphotometer / northeastern Atlantic / plankton

Résumé - Nouveau bathyphotomètre pour mesurer la bioluminescence sur le plateau continental armoricain (Atlantique nord-est). Un nouveau bathyphotomètre destiné à mesurer la bioluminescence marine in situ, entre la surface et $600 \mathrm{~m}$ de profondeur, a été réalisé au laboratoire d'océanographie de l'École navale. Il est utilisé depuis 1994, associé à une bathysonde Seabird $®$ et à un fluorimètre Seatech $®$. Une méthode statistique permettant de distinguer le bruit de fond bioluminescent des pics de bioluminescence a été utilisée. Des résultats obtenus en janvier et avril 1995, sur le plateau continental Armoricain, à l'ouvert de la baie de Douarnenez et dans le nord du golfe de Gascogne, sont présentés. L'activité lumineuse peut être reliée aux variations saisonnières de la production planctonique, faible l'hiver, plus élevée au printemps. (C) Elsevier, Paris / Ifremer / Cnrs / Ird
\end{abstract}

bioluminescence marine / bathyphotomètre / Atlantique nord-est / plancton

\section{INTRODUCTION}

Bioluminescence is the emission of light by living organisms, e.g. bacteria, planktonic algae, crustacea and fish [14]. Wavelengths of peak bioluminescence emission range between 450 and $510 \mathrm{~nm}$. Since some species of toxic dinoflagellates are bioluminescent, the understanding of bioluminescence mechanisms could help to predict toxic blooms. Bioluminescence is also often correlated to the presence of specific oceanic structures, e.g. oceanic fronts. This aspect is interesting to investigate. Bioluminescence also reveals organism concentrations and helps to quickly understand the depth distribution of pelagic organisms. All this research at sea needs specific instruments.

Bioluminescence has always been observed at the surface of oceans but it was only in the 1930s with Beebe's observations $[4,5]$ that bioluminescence was also discovered in deep waters. The first bathyphotometers appeared in the $1950 \mathrm{~s}[7,8,11]$. Bioluminescent light is often masked by ambient light from the sun or the moon so Clarke and Wertheim [11] recorded changes of incident radiation on the surface with a photometer on the deck and then adjusted the results of bioluminescence emission recorded in deep water simultaneously. Clarke and Kelly [10] and Seliger et al. [29] added a dark chamber 
which stopped the ambient sun interference with measurements. This chamber allowed the calculation of a volumetric reference, a residence time of the organisms in the chamber, and gave more precise quantitative data.

Scientists have tried to distinguish natural bioluminescence from stimulated bioluminescence, which is not easy. Natural bioluminescence, a bioluminescence measured without any human stimulation, is easily disturbed by mechanical effects due to the ship or to the bathyphotometer itself. Clarke and Kelly [9] observed these effects and used mechanical stimulation for measurement requirements. All the closed systems have a pump [10, $18,29,31-33]$. The pump can stimulate organisms in a dark chamber and generate a constant water flow. Neilson et al. [25] developed a moored bioluminescence bathyphotometer. Aiken and Kelly [1] described a bioluminescence sensor towed in the Undulating Oceanographic Recorder.

For the measurement itself, photodetectors were usually photomultiplier tubes, more sensitive than diodes. Nealson et al. [24] and Webster et al. [37] used two photomultiplier tubes to determine the distance at which light emission occurred.

The systems of Swift $[2,3,33]$ or Lapota [16] as well as the High Intake Defined Excitation Bathyphotometer (HIDEX), the towed system (TOWDEX) and the moored system (MOORDEX) [6], measure physical and biological parameters at the same time as bioluminescence [38].

$\Lambda$ bathyphotometer was designed and built in the laboratoire d'océanographie de l'École navale (Oceanographic Laboratory of the French Naval Academy, in Brest) to measure stimulated bioluminescence at sea on vertical profiles between the surface and $600 \mathrm{~m}$ depth. With this new type of bathyphotometer, only bioluminescence arising from organisms smaller than $2 \mathrm{~mm}$ was measured. A systematic study of bioluminescence has been made off Britanny since 1994 to study seasonal variations on the continental shelf, especially on the hydrological fronts and many bioluminescent profiles have been obtained.

\section{MATERIAL AND METHODS}

The bathyphotometer (figure 1), was used as an additional probe of a CTD SBE25 $®$, with a ScaTech $®$ fluorometer and a centrifugal pump mounted on the bathyphotometer in order to provide a constant stimula- tion. The submersible Challenger Oceanic centrifugal pump had a timer to switch the pump on in the water. It was also programmed to be stopped in the water, and lubricated by water. The CTD switched on the bathyphotometer when the system was in water. All the data were stored in the CTD until they were downloaded to a PC on deck and treated with Seasoft software analysis. All the instruments had their own rechargeable batteries.

The detector in this bathyphotometer was a photomultiplier tube (PMT) Philips XP2081, it measured light coming through a neutral density filter (Ealing 26-5967 transmission $40 \%$ ) and a window ( $90 \%$ transmission). It has been chosen for its spectral sensitivity, very high at the wavelengths between $440 \mathrm{~nm}$ and $570 \mathrm{~nm}$ corresponding to the range of the blue-green bioluminescent light emitted by living organisms. Electronic treatment was separated into three steps: amplification, integration and dynamic compression. The signal coming from the detector was first linearly amplified because of the low amplitude of the signal. The following integration lasting $0.5 \mathrm{~s}$ gave a dc voltage representing a mean value of the different flashes emitted in the dark chamber during this time. The third part of the electronic treatment was a logarithmic transformation of the data.

Seawater was pumped through a dark hose $(17 \mathrm{~mm}$ diameter), which stopped ambient light from coming in, and through a rectangular dark chamber. The flow rate was fixed at $0.5 \mathrm{~L} \mathrm{~s}^{-1}$, giving a residence time in the dark chamber (volume: $0.19 \mathrm{~L}$ ) of approximately $0.45 \mathrm{~s}$. The turbulent flow rate was recorded by a mechanical displacement flowmeter at the pump output. A grid of $2 \mathrm{~mm}$ mesh at the entrance of the chamber stimulated organisms which emitted light in front of a window and a detector. Light was converted into a dc voltage and stored in the permanent memory of the CTD, every 2 or $4 \mathrm{~s}$ depending on the CTD configuration.

The instruments could be used in vertical profiles down to $600 \mathrm{~m}$ depth, limited in depth by the pump housing. When the pump was stopped, there was no bioluminescent signal detected. When the grid was removed, the signal was very weak.

Water samples were taken for chlorophyll $a$ determination. They were filtrated on GF/F filters and analyzed using spectrofluorometry following the proceedings described by Neveux and Panouse [26]. A single calibration was made between the fluorometer measurements and the chlorophyll $a$ samples for all stations and all depths. 

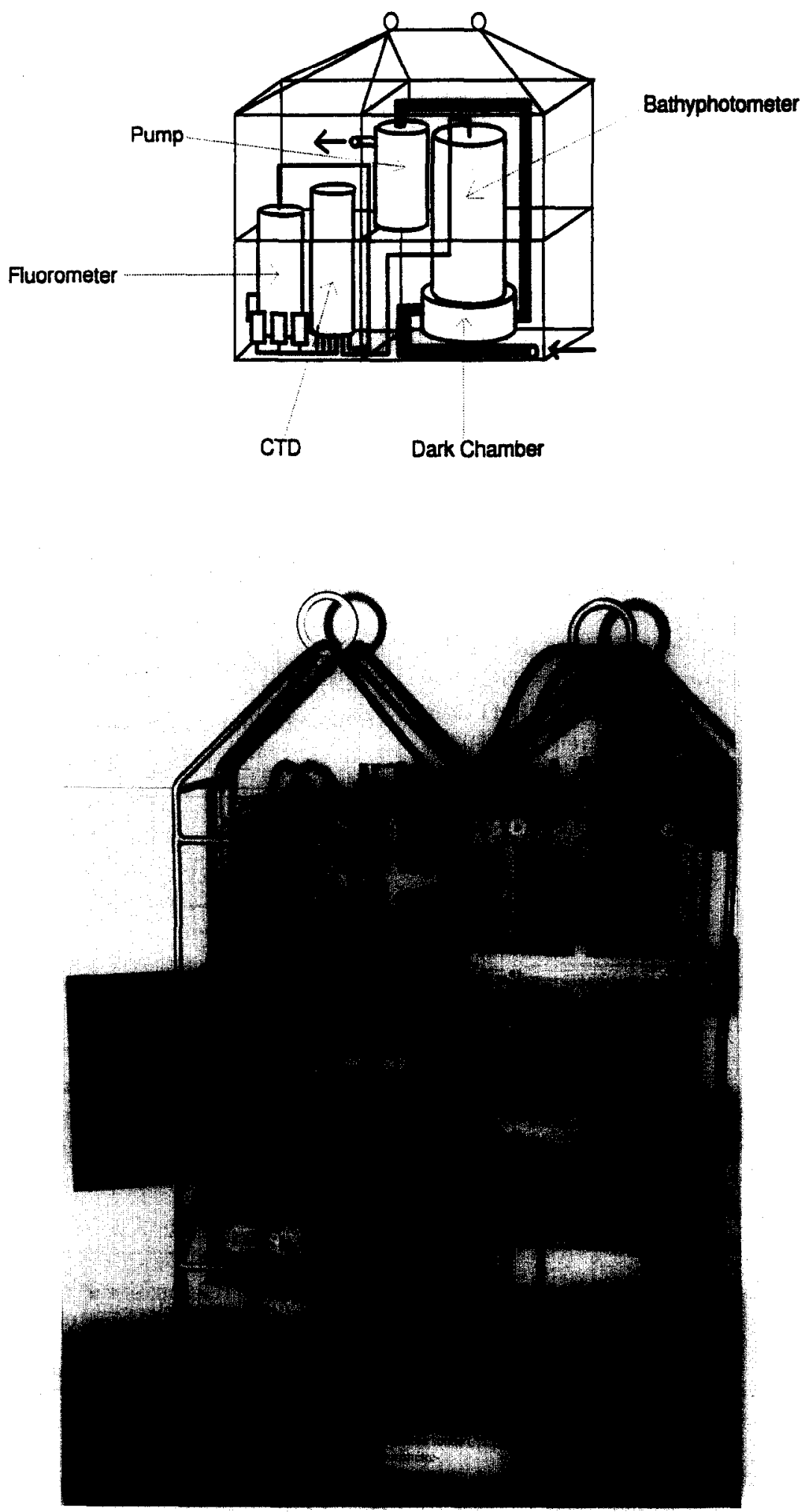

Figure 1. The bathyphotometer associated with a CTD SBE25, a SeaTech®fluorometer and a centrifugal pump. Diagram and photograph. 


\subsection{Bathyphotometer calibration}

The output voltage $U$ measured from the bathyphotometer must be expressed in power flux describing the bioluminescence light passing through the neutral filter and the window of the bathyphotometer. The output voltage is linked to the gain $G$ and to the offset $O$ characteristic of the PMT. The values of $G$ and $O$ are dependent on the wavelength of the incident light. The equation between the output voltage $U$ and the incident flux $F$ can be written as:

$\mathrm{U}=\log [\mathrm{G}(\lambda) * \mathrm{~F}+\mathrm{O}(\lambda)]$

( $U$ = PMT output voltage in volts; $F=$ incident flux in $\mu \mathrm{W} \mathrm{cm}{ }^{-2} ; \mathrm{G}=$ gain of the PMT; O = offset of the PMT)

The objective of the calibration was to find the optimum gain and offset.

\subsubsection{Calibration system}

The calibration system (figure 2) was made of a light source (lamp), a monochromator with a wavelength accuracy of $\pm 0.2 \%$, a calibrated sphere, a reference PMT and the bathyphotometer to be calibrated. The reference PMT and the bathyphotometer's PMT were put in the same experimental conditions. Light, with a known wavelength, was diffused in a sphere where two holes with the same surface received two equal powered beams, one turned towards the bathyphotometer and one towards the reference photomultiplier tube. The incident flux density $\mathrm{R}$ coming to the reference PMT as a diffused light was calculated from the dc voltage measured at the output of the reference PMT as:

$\mathrm{R}$ in $\mu \mathrm{W} \mathrm{cm} \mathrm{cm}^{-2}=$ reading in volts / (sensitivity $\times$ gain)

with the sensitivity given by the manufacturer for each wavelength.

Sets of measurements were repeated for six wavelengths: $470,480,490,500,510$ and $520 \mathrm{~nm}$. As the bioluminescence spectrum was unknown, six equations giving $U=$ $\log \left[G_{\lambda} \cdot F+O_{\lambda}\right]$ for each wavelength were then considered and the optimum gain $G$ and offset $O$ were calculated by means of statistics.

\subsubsection{Estimation of gain $G$ and offset $O$}

From equation (1), we got $10^{\mathrm{U}}=\mathrm{G}_{\lambda} \cdot \mathrm{F}+\mathrm{O}_{\lambda}$

$$
\text { or } \quad F=\left(10^{U}-O_{\lambda}\right) / G_{\lambda}
$$

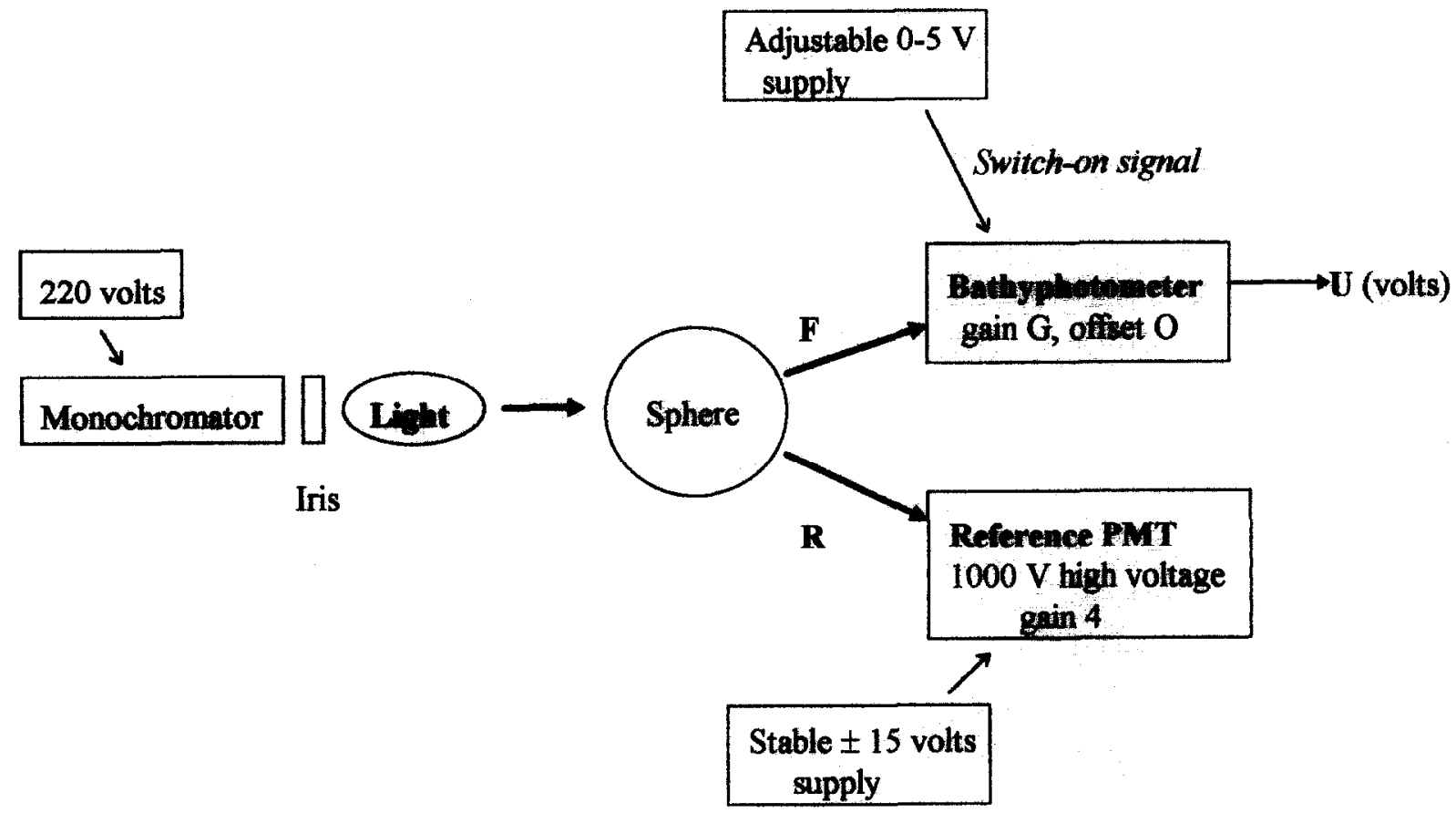

Figure 2. Diagram of the calibration system of the bathyphotometer. The arrow shows the path of the light. 


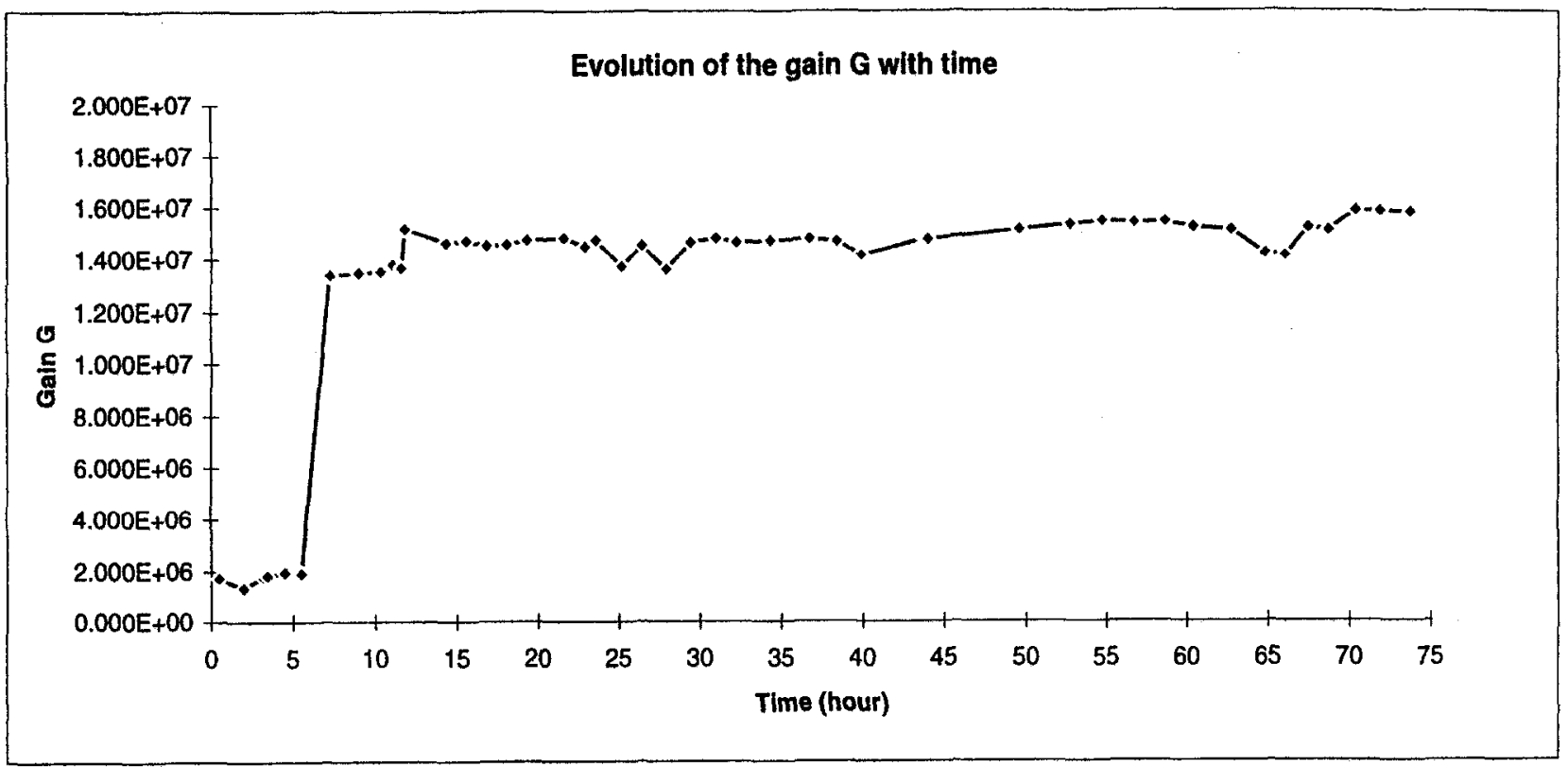

Figure 3. Variations of the gain and offset with time (see text).

We looked for the parameters $G$ and $O$ to predict $F$ assuming $\mathrm{F}=\mathrm{R}$.

If $\mathrm{V}=10^{\wedge} \mathrm{U}$, we had the linear equation:

$$
\begin{aligned}
& R & =\left(1 / G_{\lambda}\right) \cdot V-\left(O_{\lambda} / G_{\lambda}\right) \\
\text { or } & R & =\beta 1 . V+\beta 0
\end{aligned}
$$

with $\beta 1=1 / G_{\lambda}$

$\beta 0=-O_{\lambda} / G_{\lambda}$

giving $G_{\lambda}=1 / \beta 1$

$$
\mathrm{O}_{\lambda}=-\beta 0 / \beta 1
$$

From statistical tests for the calibration we found the six equations had the same slope but the constant was different depending on the wavelength. Bioluminescence emission in the environment covers different wavelengths and the best measurements of bioluminescence were made with low band filters used successively.

A common straight line was then calculated and $\beta 0$ and $\beta 1$ were estimated with their $95 \%$ confidence intervals.

The common straight line was $R=0.068 \mathrm{~V}-0.073$

with: $\beta 0=-0.073 \pm 0.010$

$\beta 1=0.0680 \pm 0.0007$ giving: $1.486 \times 10^{7} \geq \mathrm{G}_{\lambda} \geq 1.456 \times 10^{7}$ and

$$
1.231 \geq O_{\lambda} \geq 0.917
$$

Then,

$$
\mathrm{F}=\left[10^{\mathrm{U}}-1.074\right] /\left(1.471 \times 10^{7}\right)
$$

for January.

Statistical tests and calculations on calibration in April gave about the same results as in January. The common straight line had the following equation:

$\mathrm{R}=0.067 * \mathrm{~V}-0.073$

with : $\beta 0=-0.073 \pm 0.010$

$\beta 1=0.0670 \pm 0.0007$;

giving: $1.508 \times 10^{7} \geq \mathrm{G}_{\lambda} \geq 1.477 \times 10^{7}$

$1.252 \geq \mathrm{O}_{\lambda} \geq 0.931$

Then, for April

$\mathrm{F}=\left[10^{\mathrm{U}}-1.092\right] /\left(1.493 \times 10^{7}\right)$

\subsubsection{Variations of the gain and offset with time (figure 3)}

Different offsets were present in the electronic circuit but only one could actually influence the value of the general 


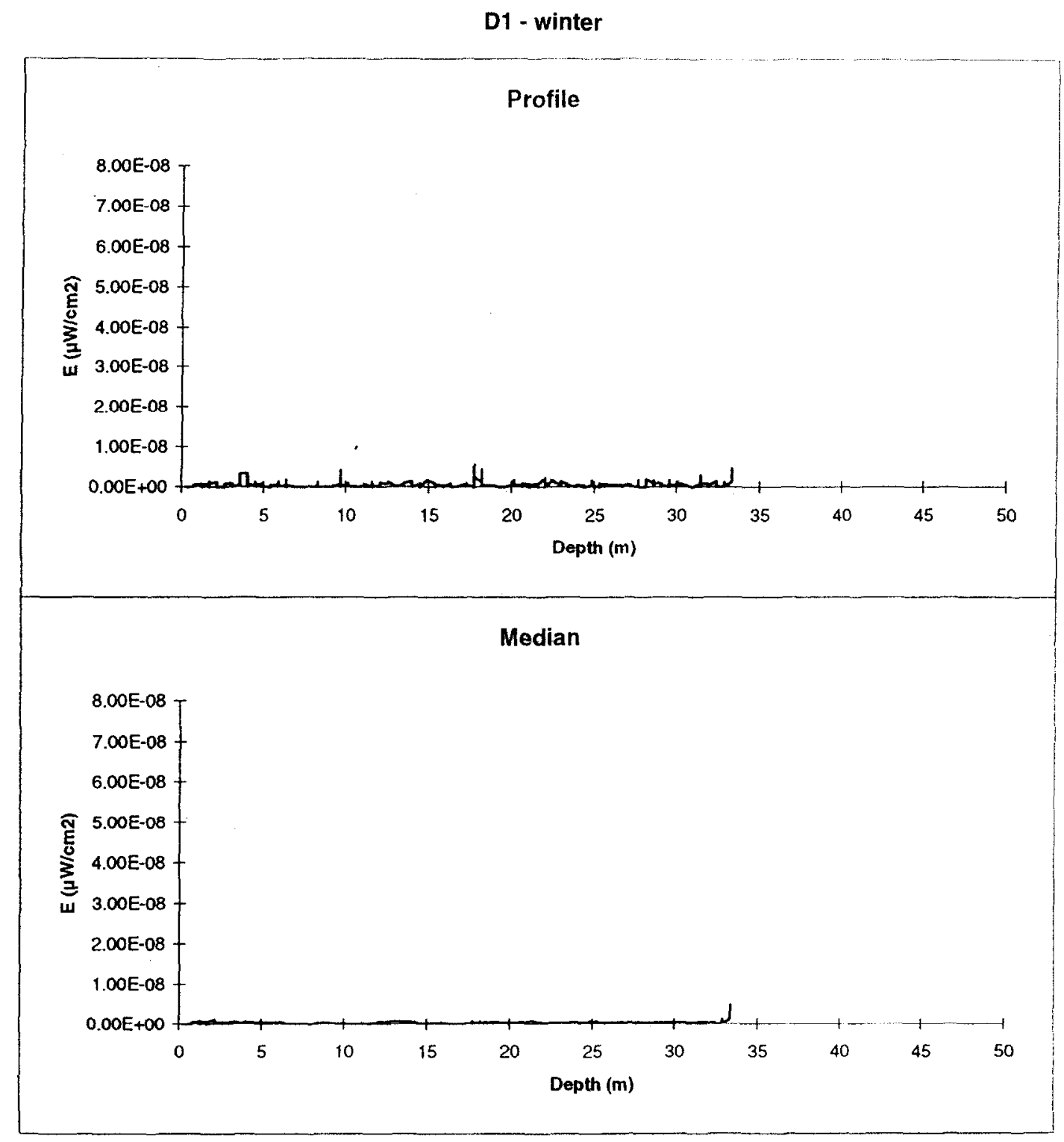

Figure 4. Stations D1, 2 and 3 - January 1995; vertical profiles of bioluminescence. Downwards: whole profile and continuous signal (see text).

offset $O$. It was fixed by the electronics engineer at a specific value with a potentiometer to know whether the bathyphotometer was working or not.

The increase does not depend on electronics but on the photomultiplier tube itself. The response drift is higher during the first $15 \mathrm{~h}$, it is then recommended to age the tube before real measurements. It is then stable over a series of measurements but can be shifted to about $\pm 0.2 \times 10^{7}$.

\subsection{Raw data processing}

Bioluminescence data were first converted in ASCII files with Seasoft (B) and then calibrated according to the equation (4) with the values of

$\mathrm{G}=1.468 \times 10^{7}$ and $\mathrm{O}=1.147$ for January and

$\mathrm{G}=1.505 \times 10^{7}$ and $\mathrm{O}=1.002$ for April 


\section{D2 - winter}

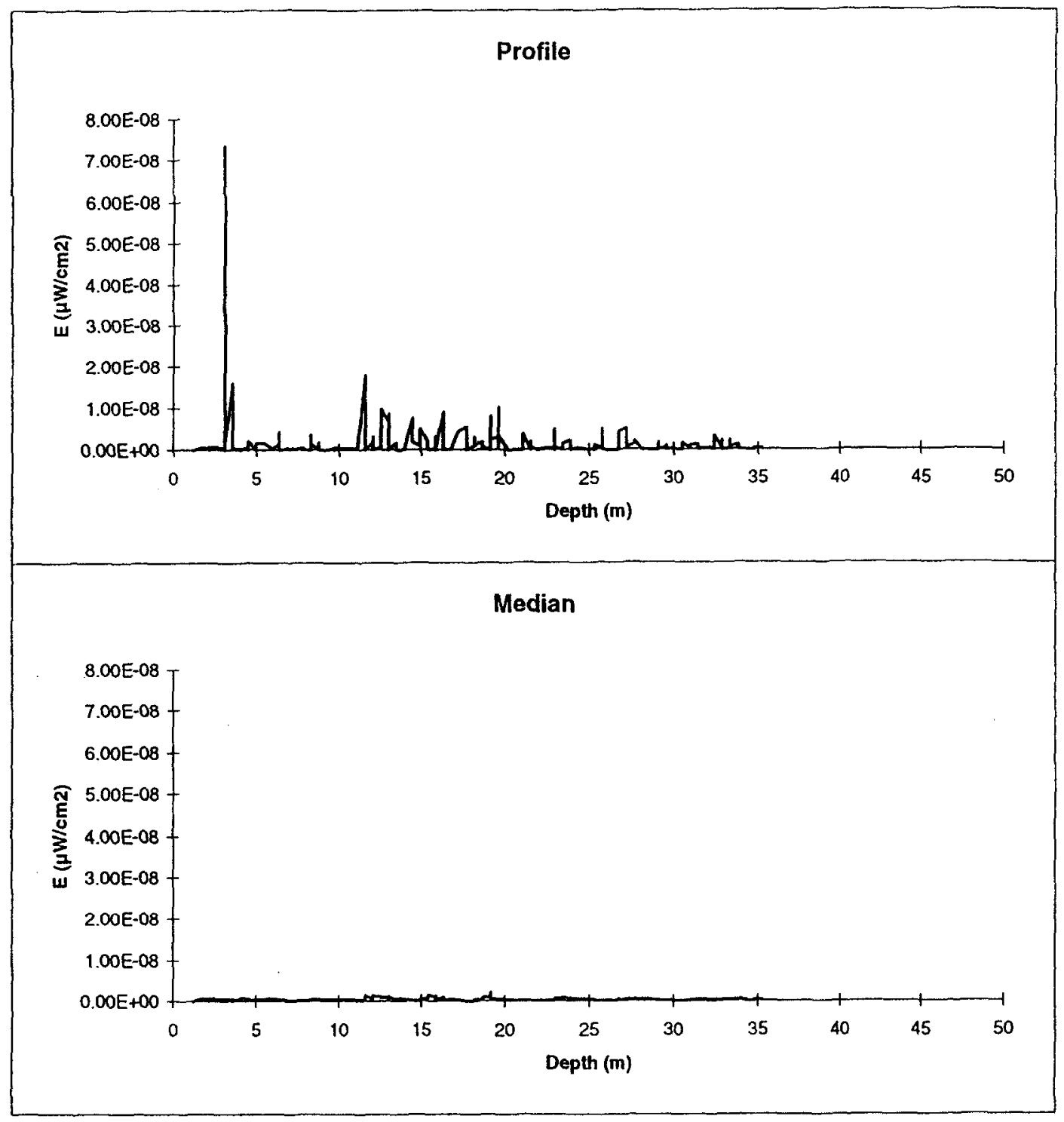

Figure 4. (Contd.)

The bioluminescence profiles (figures 4, 5, 6) show a continuous signal and sharp peaks. As the bioluminescence signal was integrated over $0.5 \mathrm{~s}$ and data taken at sampling rate of the CTD, it was not possible to distinguish each individual flash coming from isolated bioluminescent organisms. It was not possible to see if a sharp peak represented just one very intense flash in $0.5 \mathrm{~s}$, or if it was the response from several flashes; isolated peaks were then considered as a single bioluminescent event observed during time intervals of $0.5 \mathrm{~s}$.
Then these data were filtered by a running median filter with a window of three consecutive intervals. The resulting filtered series showed somewhat continuous change with depth. Substracting the filtered series from the original series led to separate peak events. This activity could then be characterized by event frequency over depth bins (for example five peaks between 5 and $10 \mathrm{~m}$ depth) and the distribution of intensity values for those peaks. Negative values were set to zero considering that the values under the median filter were negligible. Intensities less 
D3 - winter

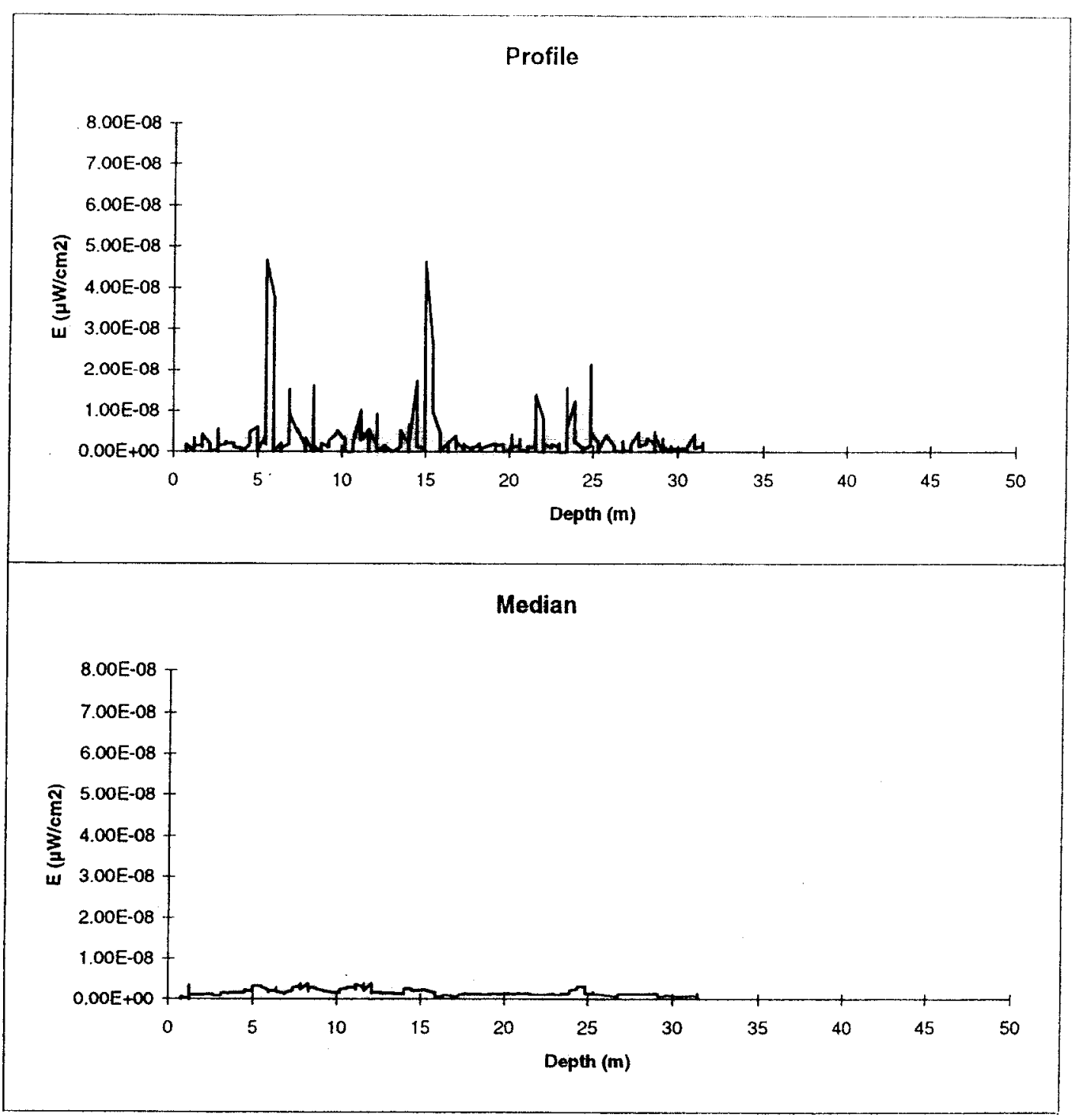

Figure 4. (Contd.)

than $1 \times 10^{-9} \mu \mathrm{W} \mathrm{cm} \mathrm{cm}^{-2}$ on the original profile are very weak and can be confused with electronic noise, but they indicate a weak bioluminescence when sharp peak intensities are studied.

Several aspects were considered in the results: filtered series as a continuous variable, total number of peaks, maximum intensities, frequency and intensity distribution of the peaks with intensities higher than $1 \times 10^{-9} \mu \mathrm{W} \mathrm{cm} \mathrm{cm}^{-2}$ in the water column.

\subsection{Study area}

The continental shelf of Brittany has been particularly investigated since 1994 by the oceanographic laboratory of the French Naval Academy, from Ushant island to the south of Brittany, with the French Navy Ships Glycine and Eglantine. No in situ bioluminescence measurements have been made so far in this area.

This continental shelf, particularly large and subject to the rhythm of tides, is characterized by three fronts: in 
winter, by a tidal haline front (Ushant front) and by the coastal tide front of Iroise, (at the entrance to the Bay of Brest and to the Bay of Douarnenez). In summer, the fronts are nearly at the same location but as thermal and thermo-haline fronts $[22,30]$. The Ushant thermal front, north-south, separates high temperature stratified western waters from cooler homogeneous coastal $[13,15,17$, $21,23,28]$. South of Brittany, low salinity water coming from the outflow of the Loire, and possibly the Vilaine, extends along the coast, this third front is the haline front of the Loire [21].

This study presents the results obtained in these areas during winter and spring, in January and April 1995. The visited stations were at $48^{\circ} 07^{\prime} \mathrm{N}$, in the coastal tide front of Iroise, off the Bay of Douarnenez, D1 at $04^{\circ} 43^{\prime} \mathrm{W}$ (49 m depth), D2 at $04^{\circ} 40^{\prime} \mathrm{W}$ (42 $\mathrm{m}$ depth) and D3 at $04^{\circ} 35^{\prime} \mathrm{W}$ (38 m depth); off the south of Brittany, P1 at $47^{\circ} 45^{\prime}, \mathrm{N}-04^{\circ} 30^{\prime} \mathrm{W}\left(85 \mathrm{~m}\right.$ depth) and P5 at $47^{\circ} 12^{\prime} \mathrm{N}$ $-5^{\circ} 00^{\prime} \mathrm{W}$ (141 m depth) (figure 7 ).

\section{RESULTS}

\subsection{Analyses of bioluminescence profiles}

During the winter (January 1995) at the entrance to the Bay of Douamenez, in the coastal tide front of Iroise (at stations D1, D2 and D3; figure 4), bioluminescence had a continuous weak activity, especially at the surface, of about $1 \times 10^{-9} \mu \mathrm{W} \mathrm{cm} \mathrm{cm}^{-2}$, but some bioluminescent peaks appeared deeper in the water column. The number of peaks of bioluminescence varied between stations; large peaks appeared between the surface and $30 \mathrm{~m}$ depth. The majority of peaks had an intensity less than $1 \times 10^{-8} \mu \mathrm{W} \mathrm{cm}$ (less than $4.5 \times 10^{-8} \mu \mathrm{W} \mathrm{cm} \mathrm{cm}^{-2}$ at D3).

At D1, outside the Bay of Douarnenez, the maximum intensity was not higher than $1 \times 10^{-8} \mu \mathrm{W} \mathrm{cm} \mathrm{cm}^{-2}$ (some peaks at $5 \times 10^{-9} \mu \mathrm{W} \mathrm{cm}^{-2}$ ) between 15 and $30 \mathrm{~m}$ depth. Considering the median filter, bioluminescence background was less than $1 \times 10^{-9} \mu \mathrm{W} \mathrm{cm}$ which was very weak. For the two stations D2 and D3, bioluminescence background was between 1 and $2 \times 10^{-9} \mu \mathrm{W} \mathrm{cm} \mathrm{cm}^{-2}$. In January fluorescence implied ca. $1 \mathrm{mg} \mathrm{chl} a \mathrm{~m}^{-3}$ in the Bay of Douarnenez, and negligible chlorophyll $a$ westwards (between 0.5 and $0.7 \mathrm{mg} \mathrm{chl} a \mathrm{~m}^{-3}$ ).

During the spring (April 1995) (figure 5) using the median filter, bioluminescence showed an important signal at the entrance to the Bay of Douarnenez, in the whole water column. The median level was much higher compared to January, with an intensity of about $2 \times 10^{-8} \mu \mathrm{W} \mathrm{cm} \mathrm{cm}^{-2}$; this meant that $50 \%$ of bioluminescence was superior to $2 \times 10^{-8} \mu \mathrm{W} \mathrm{cm}{ }^{2}$. A high number of sharp peaks up to $1.8 \times 10^{-7} \mu \mathrm{W} \mathrm{cm} \mathrm{cm}^{-2}$ was observed in the middle of the water column for the shallowest station (D3). Peaks appeared in the whole water column for the westernmost station, but they were weaker, with a maximum intensity of $1 \times 10^{-7} \mu \mathrm{W} \mathrm{cm} \mathrm{cm}^{-2}$. Fluorescence was much higher than in January, about $4 \mathrm{mg} \mathrm{chl} a \mathrm{~m}^{-3}$ at D3 and about $3 \mathrm{chl} a \mathrm{~m}^{-3}$ at D2.

In the northern Bay of Biscay (stations $\mathrm{P} 1$ and $\mathrm{P} 2$; figure 6), during the spring (April 1995), the median filter indicated a very high bioluminescence with $50 \%$ of the values above $2 \times 10^{-9} \mu \mathrm{W} \mathrm{cm} \mathrm{cm}^{-2}$. The continuous signal showed maxima rather at the surface or at the bottom of the water column. Bioluminescence intensities amounted to $7 \times 10^{-7} \mu \mathrm{W} \mathrm{cm}{ }^{-2}$ (only a peak at $\mathrm{P} 2$ ). But higher intensities were generally about 1 to $5 \times 10^{-8} \mu \mathrm{W} \mathrm{cm} \mathrm{cm}^{-2}$. Bioluminescence dominated at the station near the coast (P1). The fluorescence was vertically homogeneous, implying about $1 \mathrm{mg} \mathrm{chl} a \mathrm{~m}^{-3}$ except at $25-30 \mathrm{~m}$ depth where fluorescence values were between 2 and $3 \mathrm{mg} \operatorname{chl} a \mathrm{~m}^{-3}$.

\section{DISCUSSION}

The measured bioluminescence came from organisms smaller than $2 \mathrm{~mm}$ (mesh of the grid). At the studied depths on the Armorican shelf, this bioluminescence probably corresponded to bacterial, phyto- and zooplanktonic bioluminescence.

In winter, bioluminescence was almost non existent as shown by the level of the median filter profile which was generally constant and lower than $1 \times 10^{-9} \mu \mathrm{W} \mathrm{cm}$. However, in January, a few intense peaks were observed at the level of the coastal tidal front of Iroise. This low activity rather took place in the middle or at the bottom of the water column. Plankton in winter was rare but some phyto- and zooplankton could have been present at most of the stations. Bioluminescence was much more important in April than in January with intensities up to $1 \times 10^{-6} \mu \mathrm{W} \mathrm{cm}{ }^{-2}$. The more intense peaks were found at the stations in the Bay of Biscay. Bioluminescence appeared to be stronger near the coast. The total number of peaks was compared between the two months, the number was higher in April at the stations where high bioluminescence was measured compared to the same stations in January. 


\section{D1 - spring}

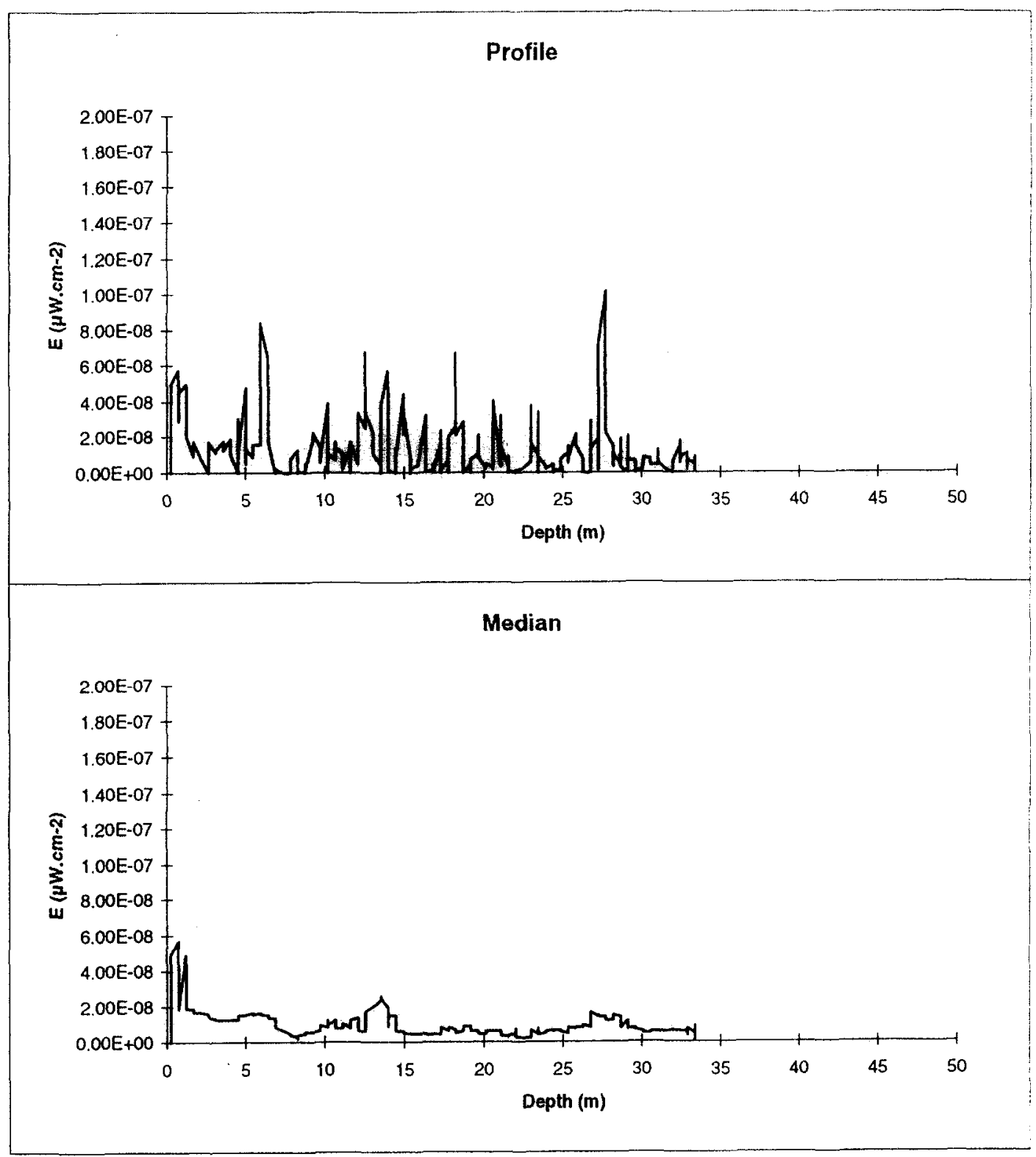

Figure 5. Stations D 1 and 3 - April 1995; vertical profiles of bioluminescence. Downwards: whole profile and continuous signal (sce text).

Stations where continuous bioluminescence occurred did not necessarily correspond to stations with intense sharp peaks. Sharp peaks, i.e. occasional bioluminescence, reached intense values but not continuous bioluminescence.

Results in bioluminescence agreed with the biological activity of the ecosystem. Bioluminescence was almost non existant in winter which corresponded to the low level of phytoplankton - less than $0.5 \mathrm{mg} \mathrm{chl} a \mathrm{~m}^{-3}[22]$ and increased in April when phytoplankton started growing. Measurements of bioluminescence could then be related to the presence of higher fluorescence. In the north Atlantic a few authors described the variations of surface bioluminescence which had often its maxima during spring 


\section{D3 - spring}

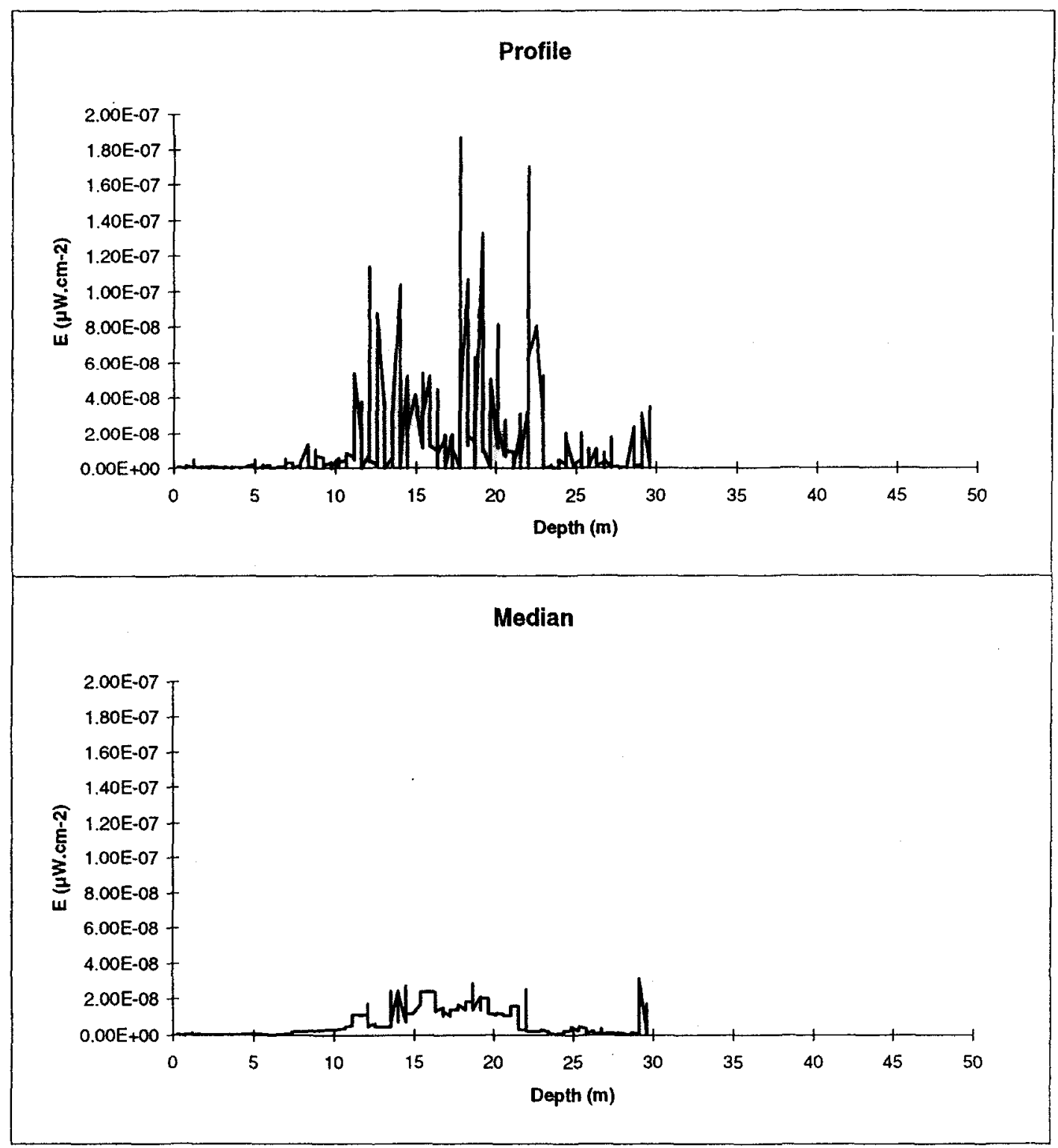

Figure 5. (Contd.)

and summer $[19,34,39]$. The high productivity marine areas are the high bioluminescence activity areas $[35,36]$. In the North Atlantic, correlation of the bioluminescence with chlorophyll fluorescence has been observed, e.g. by Neilson et al. [25] and Ondercin et al. [27].

The bathyphotometer with its present configuration does not allow the recognition of species corresponding to the specific bioluminescence profile. As it integrates emitted light over $0.5 \mathrm{~s}$, it is not possible to distinguish the number of flashes emitted in the dark chamber and their specific intensities.

This study discusses the continuous variations of bioluminescence (running median filtered series) as well as specific bioluminescent events (sharp peaks, by substract- 
P1 - spring

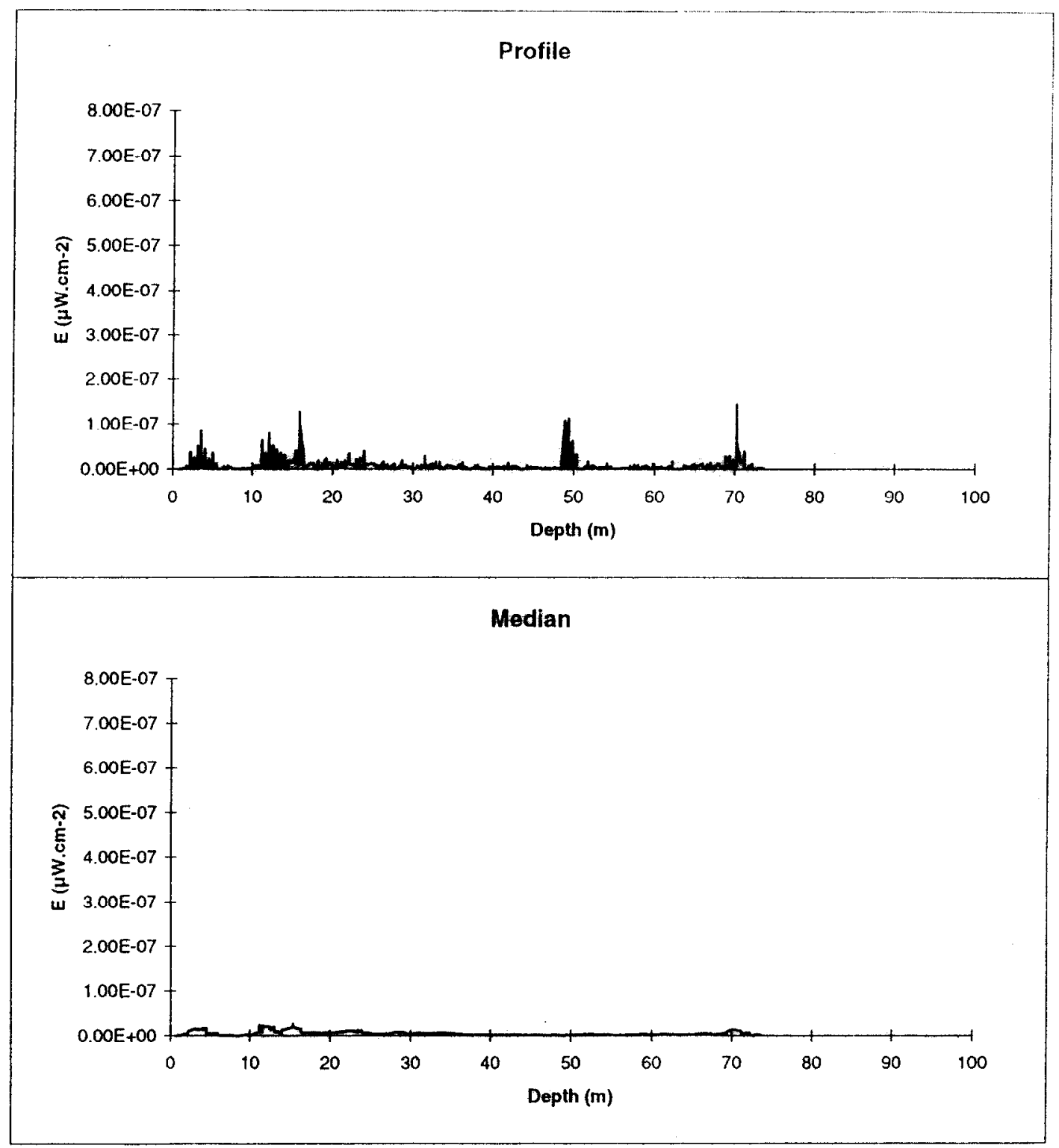

Figure 6. Stations PI and 2 - April 1995; vertical profiles of bioluminescence. Downwards: whole profile and continuous signal (see text).

ing median filter from the original profile) to understand the bioluminescence occurrence.

\section{CONCLUSION}

Bioluminescence is highly correlated to the different parameters of its environment. A study of these correla- tions over a year is being processed and will play a part in the understanding of ecosystems and relationships between planktonic species and their physical environment as well as the importance of light in the sea.

It can give interesting information on the ecosystems and planktonic life associated with other parameters of the sea (temperature, salinity, tides, wind, light, nutrients) [20]. 


\section{P2 - spring}

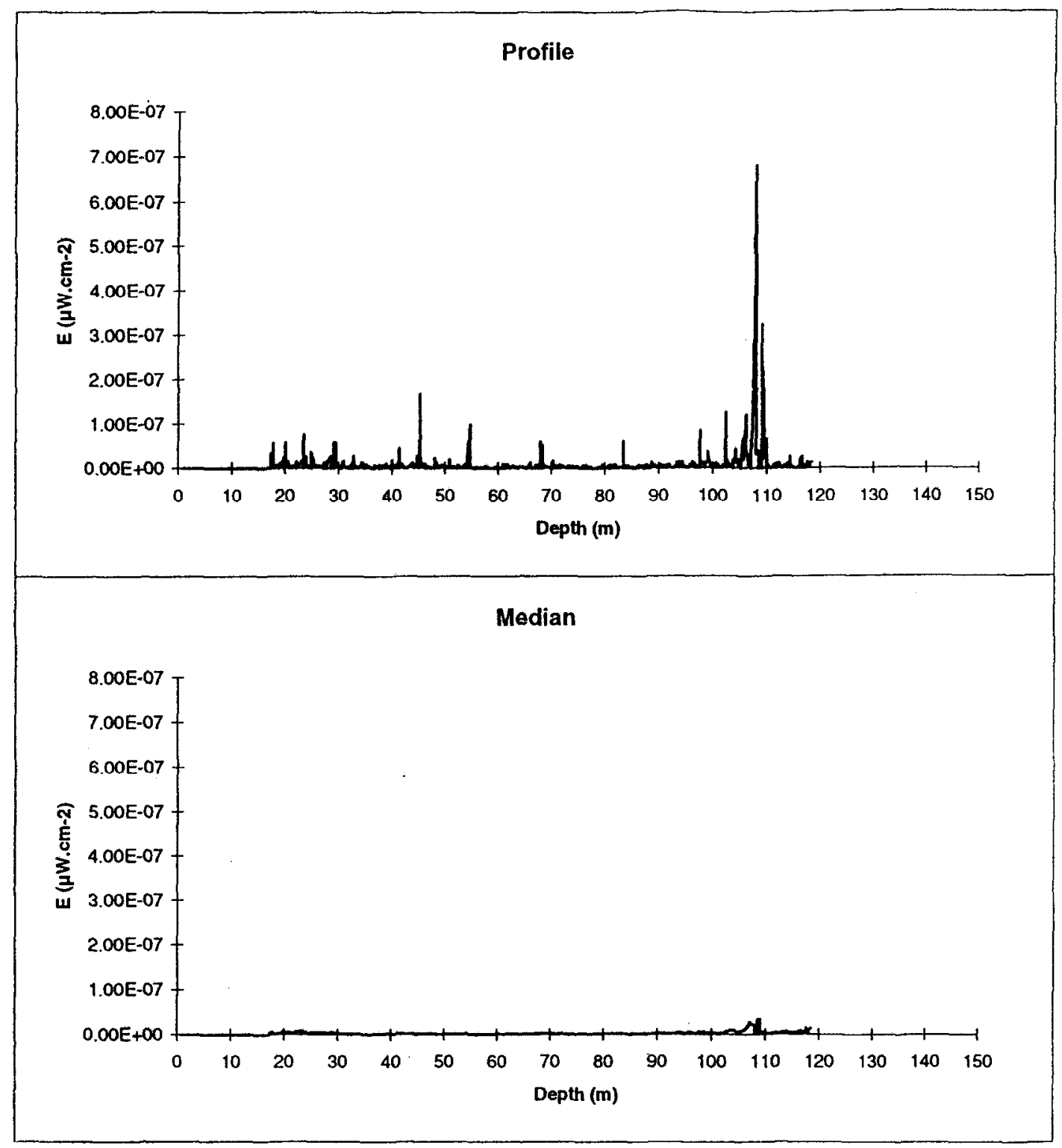

Figure 6. (Contd.)

Calibration is important as the characteristics of the photomultiplier tube vary as it becomes worn. Acquisition systems should be standardized at the international level, so that bioluminescence data can be compared between different areas in the world and between different teams.

The bathyphotometer has proved its reliability in a scries of measurements at sea with sometimes difficult weather conditions and has shown the utility of bioluminescence measurements as an indicator of biological activity. It can be easily rearranged for having real time data with a conducting cable. It was used in August 1994, aboard the RRS Discovery II, in the Arabian Sea [12]. This is a new system measuring both biological and physical parameters (chla, temperature, salinity, pressure); it is the only one measuring bioluminescence at such a depth $(600 \mathrm{~m})$ and is compact and easy to manipulate on board any ship. 


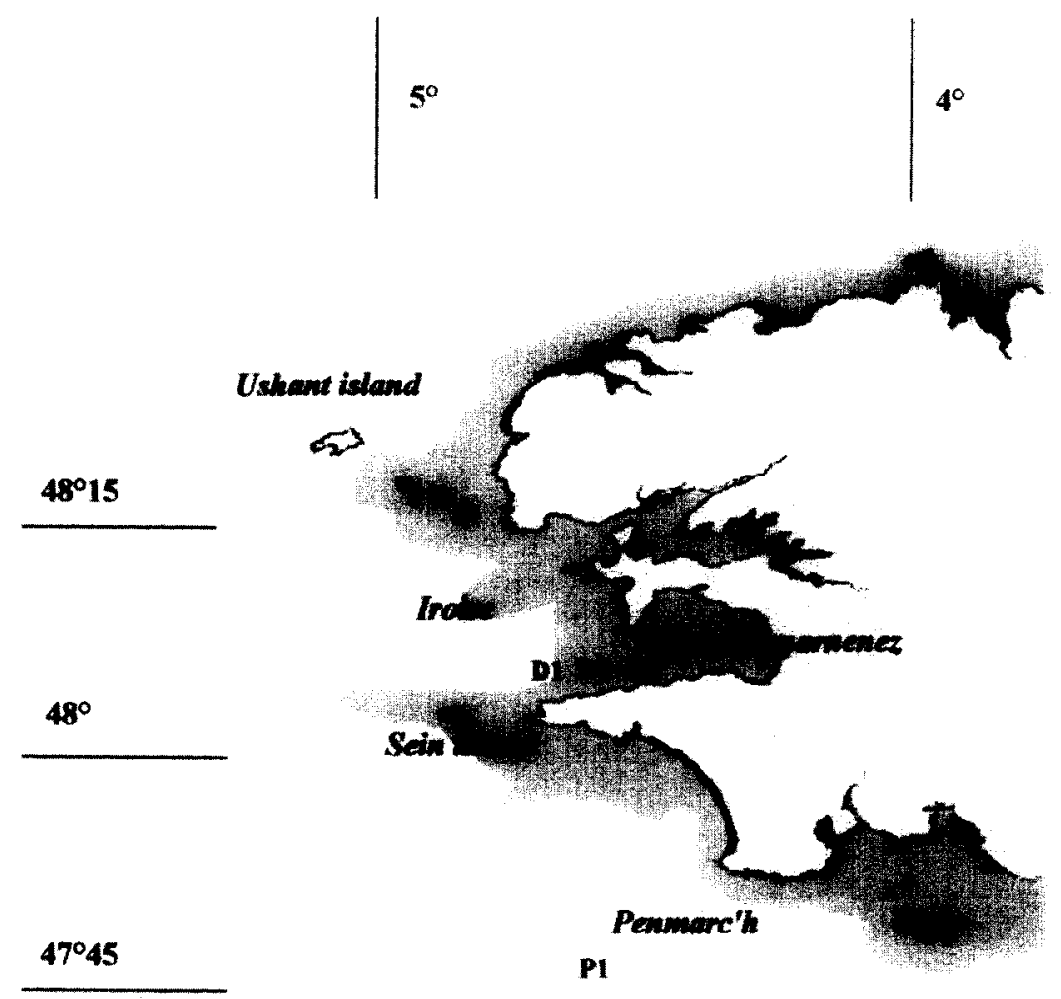

Figure 7. Station maps.

\section{Acknowledgments}

The authors wish to thank Marc Caiveau for his permanent assistance during activities of the oceanographic laboratory of the French Naval Academy, and Serge Dallot for his help at the time writing of this paper. Thanks also to the crews of the ships Glycine and Eglantine.

\section{REFERENCES}

[1] Aiken J., Kelly J., A solid state sensor for mapping and profiling stimulated bioluminescence in the marine environment, Cont. Shelf Res. 3, 4 (1984) 455-464.

[2] Batchelder H.P., Swift E., Van Keuren J.R., Pattern of planktonic bioluminescence in the northern Sargasso Sea, Mar. Biol. 104 (1990) 153-164.

[3] Batchelder H.P., Swift E., Van Keuren J.R., Diel patterns of planktonic bioluminescence in the northern Sargasso Sea, Mar. Biol. 113 (1992) 329-339.

[4] Beebe W.M. Deep-sea fishes of the Bermuda oceanographic expeditions, Introduction, Zoologica, N.Y. 16 (1933) 15-91.
[5] Beebe W.M., Preliminary list of Bermuda deep-sea fish, Zoologica, N.Y. 22 (1937) 197-208.

[6] Case J.F., Widder E.A., Bernstein S., Ferre K., Young D., Latz M.I., Geiger M., Lapota D., Assessment of marine bioluminescence, Naval Research Reviews, Office of Naval Research XLV/2 (1993) 31-41.

[7] Clarke G.L., Backus R.H., Measurement of light penetration in relation to vertical migration and records of luminescence of deep-sea animal, Deep-Sea Res. 4 (1956) 1-14.

[8] Clarke G.L., Hubbard C.J., Quantitative records of the luminescent flashing of oceanic animals at great depths, Limnol. Oceanogr. 4 (2) (1959) 163-180. 
[9] Clarke G.L., Kelly M.G., Variation in transparency and in bioluminescence on longitudinal transects in the western indian ocean, Bull. Inst. Oceanogr. Monaco 64 (1964) 1319, $20 \mathrm{p}$.

「10] Clarke G.L., Kelly M.G., Measurements of diurnal changes in bioluminescence from the sea surface to 2000 meters using a new photometric device, Limnol. Oceanogr. 10 supp. (1965) 54-66.

[11] Clarke G.L., Wertheim G.K., Measurements of illumination at great depths and at night in the Atlantic ocean by means of a new bathyphotometer, Deep-Sea Res. 3 (1956) 189-205.

[12] Geistdoerfer P., Vincendeau M.A., Bioluminescence profiles in Arabian Sea, in: Herring P., (Ed.), RRS Discovery Cruise 209, 8-22 August 1994, Biological and physical studies of the oxygen minimum and other hydrographic features of the Arabian Sea at $19^{\circ} \mathrm{N} 59^{\circ} \mathrm{E}$ during the south west monsoon, IOSDL, Wormley, UK, 1994, 26-27.

[13] Grepma A physical, chemical and biological characterization of the Ushant tidal front, Int, Revue ges. Hydrobiol. 73 (1988) 511-536.

[14] Herring P., Bioluminescence in action, Academic Press Publ., New York, 1978, $570 \mathrm{p}$.

[15] Holligan P.M., Biological implications of fronts on the northwest European continental shelf, Phil. Trans. R. Soc. Lond. A302 (1981) 547-562.

[16] Lapota D., Geiger M.L., Stiffey A.V., Rosenberg D.E., Young D.K., Correlations of planktonic bioluminescence with other oceanographic parameters from a Norwegian fjord, Mar. Ecol. Prog. Ser. 55 (1989) 217-227.

[17] Le Fèvre J., Grall J.R., On the relationships of noctiluca swarming off the western coast of Brittany with hydrological features and plankton 3characteristics of the environment, J. Exp. Mar. Biol. Ecol. 4 (1970) 287-306.

[18] Losee J.R., Lapota D., Bioluminescence measurements in the Atlantic and Pacific, in: Nealson K., (Ed.), Bioluminescence, Current perspectives, Burgess, Minneapolis, 1981, 143-152.

[19] Lynch R.V., Patterns of bioluminescence in the oceans, U.S. Naval Res. Lab. Rep. 8475 (1981) 32 p.

[20] Marra J., Bioluminescence and optical variability in the ocean: An overview of the Marine Light-Mixed Layers Program, J. Geophys. Res. 100 C4 (1995) 6521-6525.

[21] Morin P., Le Corre P., Le Fevre J., Assimilation and regeneration of nutrients off the west coast of Brittany, J. Mar. Biol. Ass. UK 65 (1985) 677-695.

[22] Morin P., Le Corre P., Marty Y., L'Helgue S., Evolution printanière des éléments nutritifs et du phytoplancton sur le plateau continental armoricain (Europe du Nord-Ouest), Oceanol. Acta 14 (3) (1991) 263-279.

[23] Morin P., Wafar M.V.M., Le Corre P., Estimation of nitrate flux in a tidal front from satellite-derived temperature data, J. Geophys. Res. 98 C3 (1993) 4689-4695.

[24] Nealson K.H., Arneson A.C., Bratkovitch A., Preliminary results from studies of nocturnal bioluminescence with subsurface moored photometers, Mar. Biol. 83 (1984) 185- 191.
[25] Neilson D.J., Latz M.I., Case J.F., Temporal variability in the vertical structure of bioluminescence in the North Atlantic Ocean, J. Geophys. Res. 100 (C4) (1995) 6591-6603.

[26] Neveux J., Panouse M., Spectrofluorometric determination of chlorophylls and pheophytins, Arch. Hydrobiol. 109 (4) (1987) 567-581.

[27] Ondercin D.G., Atkinson C.A., Kiefer D.A., The distribution of bioluminescence and chlorophyll during the late summer in the North Atlantic: maps and predictive model, J. Geophys. Res. 100 (C4) (1995) 6575-6590.

[28] Pingree R.D., The advance and retreat of the thermocline on the continental shelf, J. Mar. Biol. Ass. UK 55 (1975) 965974.

[29] Seliger H.H., Fasties W.G., Mc Elroy W.D., Towable photometer for rapid area mapping of concentrations of bioluminescent marine dinoflagellates, Limnol. Oceanogr. 14 (5) (1969) 806813.

[30] Sournia A, Brylinski J.M., Dallot S., Le Corre P., Leveau M., Prieur L., Froget C., Fronts hydrologiques au large des côtes françaises: Les sites ateliers du programme Frontal, Oceanol. Acta 13 (4) (1990) 413-438

[31] Swift E., Biggley W.H., Lessart E.J., Macroscale properties of oceanic bioluminescence: Epipelagic distributions in the Sargasso Sea,The Gulf Stream and the Carribean Sea, in: Zirino A., (Ed.), Mapping Strategies in Chemical Oceanography, Adv. Chem. Ser. 216 (1984) 235-258.

[32] Swift E., Biggley W.H., Verity P.G., Brown D.T., Zooplankton are major sources of epipelagic bioluminescence in the southern Sargasso sea, Bull. Mar. Sci. 33 (4) (1983) 855-863.

[33] Swift E, Sullivan J.M., Batchelder H.P., Van Keuren J., Vaillancourt R.D., Bidigare R.R., Bioluminescent organisms and bioluminescence measurements in the North Atlantic Ocean near latitude $59.5^{\circ} \mathrm{N}$, longitude $21^{\circ} \mathrm{W}$. J. Geophys. Res. 100 (C4) (1995) 6527-6547.

[34] Tett P.B., The relation between dinoflagellates and the bioluminescence of sea water, J. Mar. Biol. Ass. UK 51 (1971) 183-206.

[35] Turner R.J., Notes on the nature and occurrence marine bioluminescence phenomena, Nat. Inst. Oceanogr. Intern. Rep., B4 (1965) $30 \mathrm{p}$.

[36] Turner R.J., Marine bioluminescence, Mar. Obs. 36 (1966) 20-29.

[37] Webster M.S., Roos C.E., Roberts A., Okada A., Ohashi Y., O'Connor D., Mitiguy R., Matsuno S., March R., Learned J.G., Karl D., Clem J., Blackinton G., Bradner H., Babson J., Mechanical stimulation of bioluminescence in the deep Pacific Ocean, Deep-Sea Res. 38 (2) (1991) 201-217.

[38] Widder E.A., Bioluminescence, Sea Techn. March 1997 (1997) 33-39.

[39] Yentsch C.S., Laird J.C., Seasonal sequence of bioluminescence and the occurrence of endogenous rhythms in oceanic waters off Woods Hole, Massachusetts, J. Mar. Res. 26 (1968) 127-133. 